\title{
A CONCEPTUAL FRAMEWORK TO EXPLORE THE ENGLISH LANGUAGE LEARNING EXPERIENCES OF INTERNATIONAL STUDENTS IN MALAYSIA
}

\author{
Noor Saazai Mat Saad1 *, Harison@Hanisa Mohd Sidek², Hazleena Baharun³, \\ Mohd Mudzafar Idrus ${ }^{4} \&$ Melor Md Yunus 5 \\ 1Dr.,Universiti Sains Islam Malaysia, Malaysia, nmatsaad@gmail.com \\ ${ }^{3}$ Assoc. Prof. Dr., Universiti Sains Islam Malaysia, Malaysia, harison@usim.edu.my \\ ${ }^{3}$ Dr., Universiti Sains Islam Malaysia, Malaysia, hazleena@usim.edu.my \\ ${ }^{4}$ Dr., Universiti Sains Islam Malaysia, Malaysia, muzhafar@usim.edu.my \\ ${ }^{5}$ Assoc. Prof. Dr., Universiti Kebangsaan Malaysia, Malaysia, melor@ukm.my \\ * Corresponding Author
}

\begin{abstract}
This conceptual paper addresses the information lacuna in the amalgamation between the areas of language learning strategies and international students in Malaysia. Malaysia is considered a hybrid or mixed setting environment where English as a Second Language (ESL) meets English as a Foreign Language (EFL). Thus in dissecting the big areas of language learning strategies and international students in relation to Malaysia, it gives rise to four notions - hybrid environment, agency, out-of-class language learning strategies and acculturation strategies. Underpinned by tenets derived from four flagship theories/model - Experiential Learning Theory by Kolb, Sociocultural Theory by Vygotsky, Social Cognitive Theory by Bandura, and Second Language Acquisition Model by Ellis - a framework is conceptualised. The conceptual framework elucidates the interplay of the four notions and their connections which will inform the main purpose of the study that is to explore the English language learning experiences of the international students in Malaysia.
\end{abstract}

Keywords: conceptual framework, international students, language learning strategies, Malaysia

\section{INTRODUCTION}

Globalization has flattened the world of education opening up increased opportunities for exchanges and transfers. These activities have led to student mobility (Verbik \& Lasanowski 2007). It refers to the movement of students to other countries in the pursuance of knowledge. Foreign students have been going to countries like the UK, the US, Australia, and Canada. Indeed, United Nations Educational, Scientific and Cultural Organization (UNESCO) as cited in Verbik and Lasanowski (2007) reports that in 2005, there were 2.7 million people studying in countries that were not their home land. Seeing the potential in terms of revenue and cultural transfer (Andrade, 2006; Bell, 2008; Trevaskes et al., 2003), Malaysia is on its way to become the hub of education regionally (Kerr, 2011) and also internationally (Model for success, 2008).

In achieving this, Malaysia is opening its doors to students from other countries. These international students come from more than 150 countries all around the world (Ministry of Education (MoHE) Statistics, 2010). The 2010 statistics further indicate that there were 86923 foreigners registered as international students in public and private higher institutions in Malaysia in 2010. 
The coming of international students into the education institutions in Malaysia would mean that there is a need for a common language for interaction. In this case, English can be the common language as it is the language of technology and second most spoken language in the world (English Language History, n.d). Thus, Malaysian universities have set the English language requirement for international students. Most universities accept International English Language Testing System (IELTS) and Test of English as a Foreign Language (TOEFL) exam scores. However, in many institutions, when these international students do not fulfill the requirement, they will undergo English classes provided by department assigned by the management of the institution. This is the phase that is going to be captured in the study where the experiences of these international students utilizing language learning strategies to learn English are highlighted.

The language learning experiences are not straightforward as international students bring along with them their languages, religions, cultures, conventions, habits and other resources. This diversity provides avenues for all to learn, explore, understand and increase awareness about linguistics and culture differences and thus find a way to interact, accept, survive and even adapt to the plural cultures (Bell, 2008; Schmidt \& Jansen, 2005). Thus, it is the intention of this article to present the conceptual framework that underlays the study to unearth the experiences of a group of international students learning the English language in a new academic milieu and how the experience of each participant depicts the acculturation at the end of his/her first semester studies in a public university in Malaysia. The conceptual framework presented in this article is the initial stage of a bigger study.

\section{PROBLEM STATEMENT}

The backdrop of this study is based on the areas of language learning strategies and international students. Both have a strong body of research; with the former dating back three decades ago (Macaro, 2006; Oxford, 2011b) and the latter began even earlier, for example in 1950s in Australia with the inception of The Colombo Plan (Cuthbert et al., 2008; Dawson \& Hacket, 2006). In Malaysia, literature on language learning strategies started to gain momentum in late 1990s with the landmark doctorate study by Mohamed Amin in 1996. On the other hand, research on international students began to take shape when there was a steady flow of them into Malaysia since 1996 (Morshidi Sirat, 2008). The body of literature in Malaysia is still in its first phase (Noor Saazai et. al, 2012) as it touches only on the overall picture of the international students here. However, from the extant literature in Malaysia on language learning strategies and international students, there seems to be a dearth in the conflation of these two areas in relation to Malaysia.

\section{LITERATURE REVIEW}

This part will succinctly highlight the tenets from the four theories/model and the themes from the areas of language learning strategies and international students that give rise to the four notions (hybrid environment, agency, out-of-class language learning strategies and acculturation strategies) that form the conceptual framework.

\subsection{Theoretical Underpinnings}

\subsubsection{Experiential Learning Theory (ELT)}

This theory highlights the role of experience in the process of learning (Kolb et al., 2000).

In 1984, Kolb listed six characteristics of ELT and Kolb and Kolb discussed them again in 2005. These characteristics are the propositions derived from three earlier theorists - John Dewey, Kurt Lewin and Jean Piaget. The main tenet from ELT that is parallel to the discussion of this study is learning involves transactions between the person and the environment (Kolb, 1984; Kolb \& Kolb, 2005). This also echoes in Beard and Wilson's (2007) handbook on ELT that says learning is a 'sense-making process of active engagement between the inner world of the person and the outer world of the environment' (p.2). Kolb et al. (2005) further strengthen this concept by discussing learning space theory that emphasizes the setting that the learner is in; for example, immediate setting which is termed as microsystem involving the course and the classroom. Besides the environment, it also takes into account the people around the learner like in mesosystem that includes family members. In other words, the concept of environment in ELT also comprises of the people around the learner.

\subsubsection{Sociocultural Theory (SCT)}

Lantolf (2000) elucidates six germane tenets of SCT. SCT was propounded by Lev Vygotsky: mediated mind, genetic domains, unit of analysis, Activity Theory, internalization and inner speech, and Zone of Proximal Development (ZPD). However, this study only embraces characteristics from Activity Theory and ZPD. The former proposes that a person behaves and reacts based on his biological, social and cultural needs (Lantolf, 
2000). The latter, on the other hand, is in line with the concept of mediation which is central to SCT; where the mediator can be a tool or a person (Mamour, 2008). According to Vygotsky (1978), ZPD "is a distance between the actual developmental level...and the level of potential development as determined through problem solving under adult guidance or in collaboration with more capable peers" (p.33). In other words, ZPD highlights the role of other people - teachers and friends, in enhancing the learning process.

\subsubsection{Second Language Acquisition Model (SLA)}

A lot of studies on language learning strategies employ the SLA Model by Rod Ellis, 1994 to build the framework for investigating learners' choice or use of language learning strategies; for example Mohamed Amin (1996; 2000), El-Saleh (2002), Zamri (2004), Johari Afrizal (2005), and Izawati @ Siti Zawiyah (2008). This model identifies three sets of dimensions that explain the process of second language learning; individual learner differences, learner strategies, and outcome.

The first set deals with the individual learner differences that come in seven (7) different categories; age, aptitude, motivation, learning styles, beliefs, affective states and personality. In learning the second language, these diverse individuals operate in different situational and social environment which affects the strategies that they choose. The choice of strategies is the second set of the dimensions. Some researchers doing studies on language learning strategies have broken down this set into the type of classification/typology that they have chosen; Zamri (2004) for example has chosen to look at in-class, out-of-class and test preparation, whereas Izawati @ Siti Zawiyah (2008) looks at cognitive, metacognitive, affective, memory, compensation and social. This then goes to the third set which is the outcome. This deals with the level of achievement in attaining the second language. It has a two way relationship with the earlier set. In other words, the result of acquiring the second language depends on the strategies used.

\subsubsection{Social cognitive theory}

The core view of this theory is that "mind, body and world function integratively" (Atkinson 2011, p.143). It is to say that the cognitive, physical being and environment affect each other. Moreover, Bandura (2001, p. 2) states that, "human functioning is analyzed as social interdependent, richly contextualized and conditionally orchestrated within the dynamics of various societal subsystems and their complex interplay".

Albert Bandura discussed Social Cognitive Theory in light of the agentic perspective. Being an agent, according to Bandura (2001), is for the person to make things happen with intention. Therefore a person is responsible for one's own development, adaptation and change which depend on the environment and situation. In other words, a person can choose to act or not to act based on a reason or reasons that arise from within that is inspired by or as a resistance towards the world around him.

There are four core features of agency which are associated closely to the mind and body: intentionality, forethought, self-reactiveness, and self-reflectiveness (Bandura 2001, 2005, 2006). These features propel people to have a big role in their own self-development, adaptation and self-renewal with changing times. Being intentional suggests that a person has a reason for doing something or for not doing it. The power to do so is in the hand of that person. In line with that, the second feature - forethought which implies having goals for oneself, provides a reason for the agentic behaviour. Thus, the action or inaction, or selection of action works in tandem with the goals that one has set. However, this should not be like the cliché 'the end justifies the means', where one can do anything to achieve the goal. The third feature, self-reactiveness provides the monitoring factor to the agency that one has. The monitoring is to ensure that one works within one's cognitive and environmental conditions. Self-reactiveness is also related to motivation. The last feature is selfreflectiveness. It is to examine and evaluate the action to be taken or not to be taken. So, in exercising agency, a person is a planner, forethinker, motivator, self-regulator and self-examiner with high self-efficacy (Bandura, 2001).

\subsection{Language Learning Strategies (LLS)}

Language learning strategy is seen to be a facilitating technique to ease language learning. Its orchestrated and effective usage leads to success in language learning (Kashefian-Naeeini et al., 2011; Su, 2005; Vann \& Abraham, 1990; Oxford, 1990). One of the most prominent proponents of this area, Oxford (2011b) posits that the field of LLS is influenced by three landmark concepts in the education world: Piaget's cognitive processes, self-regulation theory by Vygotsky and self-governance or better known as the autonomy concept in 1990s. All these concepts are underpinned by the notion of learners' individuality which has myriad of interrelating factors; thus opening doors to research spanning all over the world and investigating all possible factors and elements from all sides and angles. However, this article will look into only one main area: site of research and participants involved. 
Research in LLS has seen variation in many aspects. The most apparent is the site of research and participants involved which implicates the factor of learning environment. It is one of the elements that influence learners' individuality and language learning strategy use. This is explicitly mentioned in studies and research by Oxford (1996, 2011b), El-Saleh (2002), Mohamed Amin (1996, 2000), and Green \& Oxford (1995). Besides, the importance of learning environment is evinced by the many studies conducted in different parts of the world as each location provides a unique ambiance for language learning experience, for example Taiwan (Su, 2005), Oman (Adel Abu Radwan, 2011), Turkey (Irgin, 2011), Jordan (El-Saleh, 2002), Indonesia (Johari Afrizal, 2005), Japan (Tanahashi, 2009), Lebanon (Nada, 2006), China (Gu, 2002), Thailand (Pawapatcharaudom, 2007), Korea (Lee, 2003), Palestine (Shmais, 2003), Iran (Kashefian-Naeeini \& Nooreiny, 2010) and Malaysia (Mohamed Amin, 2000; Kamarul Shukri et al., 2009; Manprit \& Mohamed Amin, 2011; Zamri, 2004).

In light of the research site and participants involved in learning English as a second or foreign language, the studies can be broken down into three big groups. Firstly, the nationals studying English as a second or foreign language in their own countries as in the cases of Malaysians studying English in Malaysia and Japanese learning English in Japan; and secondly, the students of other nationalities studying English in Englishspeaking countries like studies done by Bernat et al. (2009), Gao (2006), Griffiths (2003) and Wu (2011) involving foreign students in Australia, Britain, New Zealand and America, respectively. The third group also consists of students of other nationalities studying English but not in English-speaking countries. Instead, they study English in 'hybrid'-speaking countries (Mohamed Amin, 2000; Green \& Oxford, 1995) like Puerto-Rico. When the studies are tabulated in this manner, it can be surmised that while there is a conglomeration of studies for the first two groups; there is a paucity of research in the third group.

There are many classifications of strategies advocated by the gurus in the field of LLS, for instance Bialystok (1978), O'Malley \& Chamot (1990), Oxford (1990) and Mohamed Amin (2000). Each has a cognizance of strategies used by students in their social surroundings; they are termed as social strategies (Oxford, 1990), out-of-class strategies (Mohamed Amin, 2000) and included under socio-affective strategies, inference strategies and extended practice strategies by O'Malley \& Chamot (1990), Bialystok (1978) and Tragant \& Victori (2012) respectively. Thus, out of the many classifications listed in the literature, this study looks at the out-of-class strategies category as it is in line with this research that accentuates the importance of learning environment.

\subsection{Hybrid Environment}

Although it has been "said" in literature on English in Malaysia that English is a second language (ESL) in Malaysia (Thirusanku \& Melor, 2011, p. 2); (other examples are Foo \& Richards, 2004; Murugesan, 2003), the reality is not very clear cut such that not everyone is able to converse in English and not every place is Englishfriendly. English is learnt and used instrumentally (Mohamed Amin 2000; Lee Su Kim et al. 2010) for example to excel in exams and land a good-paying job. Furthermore, drawing from Green and Oxford's (1995, p.268) description of Puerto Rico, the environment on that island is branded as hybrid because "a great deal of potential English input is available for learners who wish to take advantage of it [Thus, it is ESL]. On the other hand, Puerto Rican learners can easily survive without using English for communication, so the island might in this respect appear to have characteristics of an EFL [English as a foreign language] setting". It is of a similar case with Malaysia because Malaysian learners can survive without using English but in the case of this study; can the international students survive too? And if they do, how do they survive? Thus, it is intriguing to discover how these sojourners use English in their out of class activities in relation to language learning.

\subsection{International Students (Iss)}

The students of other nationalities or foreign students as mentioned earlier are better known as International Students (henceforth ISs). ISs are students who have crossed geographical borders in pursuit of education. Their destination is usually the English-speaking countries like the UK, the US and Australia (Arkoudis \& Tran, 2007; Harman, 2005). There is a strong growth of research regarding them in these countries and the issues addressed range widely; for instance; preparation in adaptation to new environment (Carroll, 2005; Myles \& Cheng, 2003); transition period (Guilfoyle \& Harryba, 2009; Hellsten, 2008; Andrade, 2006); problems faced by ISs (Sawir, 2005; Novera, 2004); motivation and global issues (Jiang et al., 2009; Sayers \& Franklin, 2007); and programme intervention (Sakurai et al., 2009). There are two broad themes emerging from these studies: social and academic matters. Both issues affect each other but this study concentrates on the latter.

Research on ISs concerning their academic matters has highlighted controversial issues like 'soft-marking', plagiarism and their general inability to cope with western way of studying (Birrell, 2006; Doherty \& Singh, 2005; Trevaskes et al., 2003). Moreover, the lack of their English skills has caused concerns as documented 
by Ballard and Clanchy (1997) and Bradley and Bradley (1984). These studies might be decades old but the concern for the ISs' low proficiency level of English still prevails in current writings, for example Andrade (2006), Ferman (2003), and Thompson (2009).

Although not an English-speaking country, Malaysia, like other receiving countries, puts emphasis on English as it is the language to be used in the academic milieu. Furthermore, Yusliza and Chelliah (2010) propose proficiency in the English language as one of the seven variables that can predict the adaptation level of ISs in Malaysia. Mapping the discussion of ISs in the abovementioned studies onto the scenario in Malaysia; ISs need to obtain, for example, at least a 5.5 for IELTS to secure a place in a Malaysian higher institution. However, some are accepted into the university or higher learning institution without taking IELTS or other English language tests or the score that they get does not fulfill the language requirement as stipulated by the university but their offer is conditional. In cases like this, they need to undergo an English course at the university.

Currently, a big portion of literature about ISs in Malaysia deals mainly about their demographic information and the reasons for their decision to study here (for example Zainurin \& Muhamad Abduh (2011); Rohana Jani et al. (2010); Mohd Taib et al. (2009); Rohaizat et al. (2011)). A very insignificant number of studies has actually examined the problems among ISs in Malaysia for instance; Alavi \& Syed Mohamed (2011); Mousavi \& Kashefian-Naeeni (2011); Zuria et al. (2010); Khairi \& Rechards (2010); Manjula \& Slethaug (2011). A few of these studies have highlighted that English language is a problem for ISs. The participants in a study by Zuria et al. (2010), for instance, have highlighted that Malaysians do not speak English, Malaysians speak English with Malay accent, and lack of English usage on signage and documents. Thus, it is worthwhile to look into ISs English language learning experiences in Malaysia.

\subsection{Acculturation}

Acculturation is a term defined as "socio-cultural adjustment and acquisition of dominant cultural norms by members of a non-dominant group" (Gul \& Kolb, 2009, p.1). Therefore, it implies that the members of the minority group experience changes in dealing with the new environment. The changes are seen in five general aspects according to Berry et al. (1987): physical changes like a new place to live; cultural changes; different sets of social relationships; biological changes like new nutritional status and changes in one's psychology, behaviour and mental health status. Among the abovementioned elements, this proposed study is directly and largely linked to the change in 'behaviour' in the ISs' language learning experience as seen in their language learning strategy use. Thus, although the discussion on acculturation can be associated with other aspects like culture and psychology; this study only looks at the ISs' acculturation into their academic milieu.

Berry (2005) cautions that acculturation process is not identical for each individual as it depends on many factors, for example attitudes and behaviours. Mapping it onto the proposed study, it is how the ISs feel towards assimilating into the new academic environment and what they actually do to assimilate. Their attitudes and behaviours will be determined by the analysis of their language learning strategy used and agency exercised.

Since acculturation occurs differently for individuals, Berry (2005) posits four variations termed as Acculturation Strategies; integration, assimilation, separation and marginalization. These strategies are placed on two continuums. Each continuum has a pair of contradictory strategies. This is illustrated by Figure 1. 


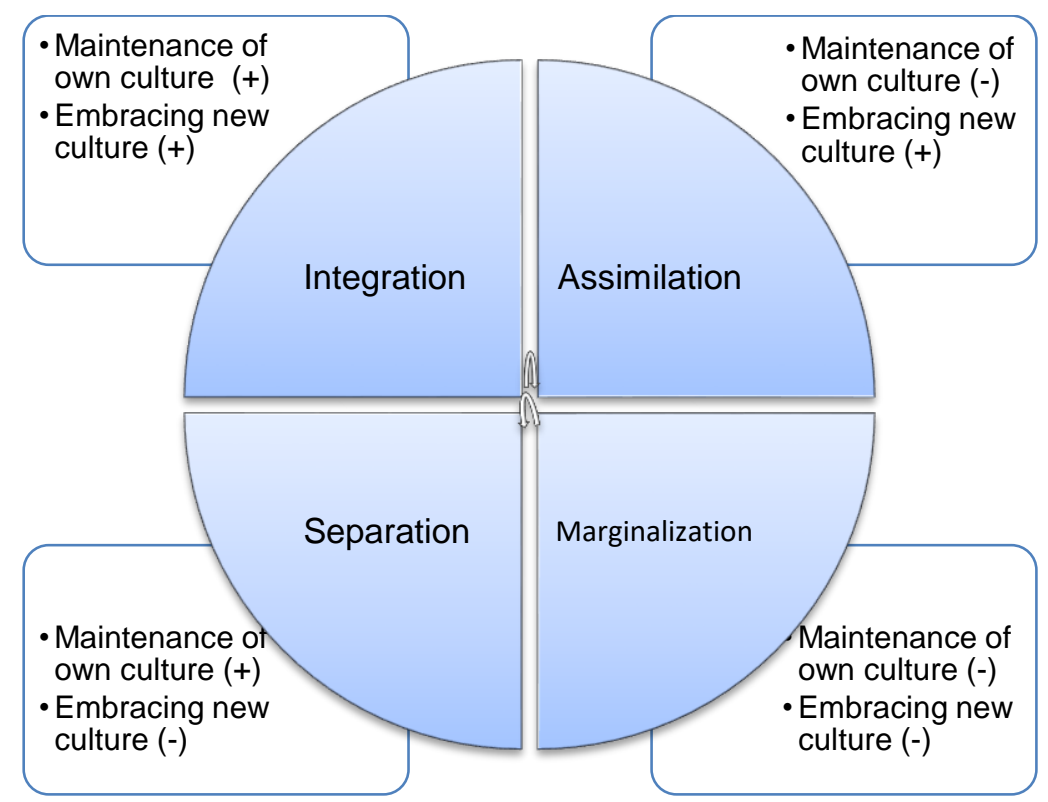

Figure 1: Four acculturation strategies adapted from Berry (2005)

The horizontal continuum is about the attitude of ISs towards own old habits (in this case, the language learning strategy use in home country) - whether to retain old habits or move away from them. The vertical continuum is about the attitude of IS in embracing new habits (in this case, the language learning strategy use to suit the new environment) or rejecting them. The first strategy, integration suggests that an IS retains old habits and also embodies new ones. Whereas, if an IS leaves old habits and embraces new ones totally, then, the strategy is assimilation. On the other hand, separation strategy is when an IS does not want to adapt to the new habits and prefers to maintain his/her old ones. And lastly, if an IS does not prefer both, then he or she is using the marginalization strategy in acculturation. The acculturation strategy that is employed by each IS is determined by the comparison of out-of-class language learning strategy use in home country and in Malaysia by the end of the period of this study.

\subsection{Agency}

According to Davies (1990), having agency is being able to set a goal and plan "a line of action, know how to achieve it and have the power and authority and right to execute it" (p.343). It is a concept that cuts across the fields of LLS and ISs. This is because in employing language learning strategies and going through acculturation as an international student; one has a goal that is to learn the English language and be able to function in the new environment, respectively. Hence, having or exercising one's agency suggests the push from within oneself that is influenced by the need of an end to be fulfilled and the action taken is within the permitted perimeter of the environment. In exercising one's agency, one can resist, negotiate, change and transform oneself (Pavlenko \& Blackledge, 2004) in order to meet the goal.

From research done involving agency and ISs, two elements have been gathered to be prevalent in their exercise of agency: imagined community and investment. Studies by Arkoudis and Love (2008) and Gu (2008) are examples of the former; while Gao et al. (2008) and Pierce (1995) discuss the latter. As an illustration, Arkoudis and Love (2008) found that the lack of use of English among students in a Mathematics class was due to their 'imagined community' because they foresaw that English would not be totally important in their future. In other words, they visualized that English would be secondary when they pursued their future endeavors in Mathematics, thus there was little need for them to be speaking the language. And on the element of investment, a study by Gao et al. (2008) is a good example. It is about Chinese students from Mainland China studying in a Hong Kong university setting up a group to practice and use English to upgrade their command of the language. The first writer, who was also one of the participants, revealed the effort put in and the time spent in pursuing their goal in being competent in the language. The effort and time are considered the 'investments' put in.

Furthermore, a qualitative study in LLS reported by Oxford et al. in Oxford (2011a) discovers that the student's lack of ability to handle second language learning crisis is due to among others, lack of 'investment'. As discussed above, 'investment' is an element related to agency. Hence, this suggests that the notion of agency 
can be utilized to explain the choice and usage of LLS.

In encapsulation, using the definition by Bandura $(2001 ; 2005 ; 2006)$ that posits personal human agency, the notion of agency can be seen in both fields discussed earlier. In fact, the studies cited show the existence of connection between agency and issues on ISs; and agency in LLS. Thus, agency is one of the aspects that differentiate the individual's English language learning experiences in this study.

\section{CONCEPTUAL FRAMEWORK}

Espousing from the four theories/model of ELT by Kolb, SLA Model by Ellis, SCT by Vygotsky and Social cognitive Theory by Bandura; and the themes discussed above, the conceptual framework illustrates the relationship among the notions of hybrid environment, agency, out-of-class language learning strategies and acculturation strategies. This part begins with a discussion on the smaller elements in each notion and then proceeds to establish the connections that exist among the notions. Both the notions and the connections are visualised in Figure 2.

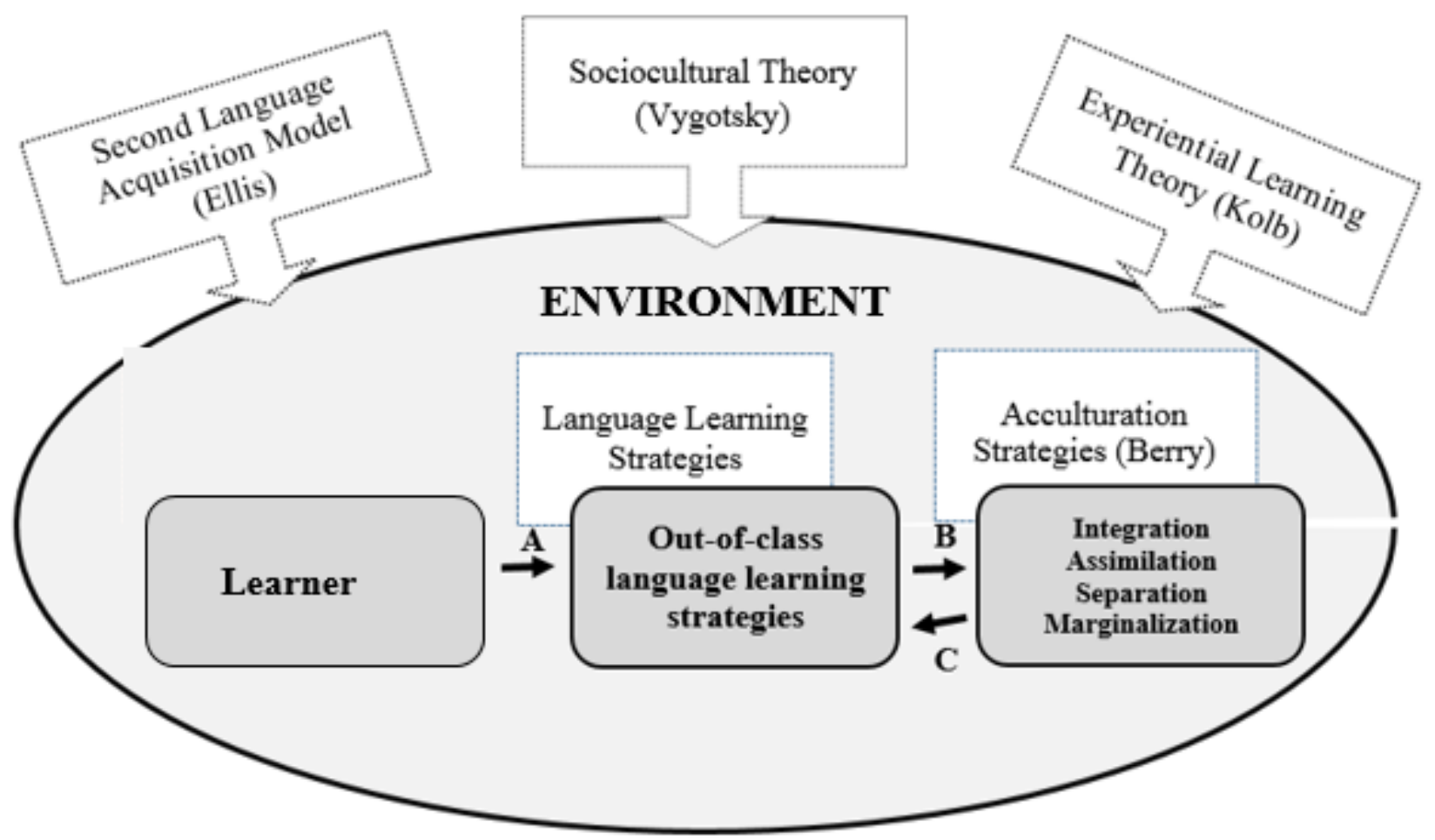

Figure 2 : Conceptual Framework

With the aim to explore the English language learning experiences of ISs, and looking through the lenses of the ELT, SCT and Social cognitive Theory; the integration of mind, body and environment happens in the process of learning. Thus, the big picture here is the environment. 'Environment' in this study encompasses Malaysia as the place of study and a Malaysian public university as the institution. Both Malaysia and the institution provide a hybrid environment for international students where ESL meets EFL. Furthermore, being in an institution, the environment involves aspects like the academic conventions, the classroom culture, and the activities in the institution, the lecturers and the peers.

With the importance of environment established as the backdrop of the study, the discussion moves on to the process of language learning. In illuminating this, the SLA Model is adapted. There are three sets in the process. The first set is individual differences which in this conceptual framework are made up of personal human agency as advocated by Bandura $(2001,2005)$ in his Social cognitive Theory. The exploration of human agency involves knowing the person's motivation, goals in the learning process and one's will to adapt to the new environment - to use all resources in achieving the goals.

The second set is as specified in the original model by Ellis in 1994. This study also uses LLS as the bridge in learning. However, the focus is on one type of strategy - out-of-class language learning strategies. It is significant as to illustrate the influence of the hybrid environment on the strategies chosen.

The third set in the adapted model is the acculturation strategies. Acculturation is an inevitable process for 
international students as they try to adapt to the new environment. However, each goes through acculturation differently. This set lists four (4) acculturation strategies that might be embraced by the students at the end of this study. They are integration, assimilation, separation and marginalization.

The notions in the conceptual framework are meaningless without the elucidation of how they are connected. Referring to Figure 2, firstly, it is clear that the process of learning for the international students occurs in the hybrid environment as the three sets of dimensions are located in the big oval representing the environment. This also portrays the influence of setting on the language learning process of ISs. Secondly, arrow A indicates the relationship between individual personal agency and the strategies used. Then, arrow B shows the connection between the out-of-class strategies used and the acculturation strategies that the students adopt. This is seen in the maintenance and/or rejection of the old (in home country) and new (in Malaysia) language learning strategies. Lastly, the study is also interested in exploring the two-way relationship between the acculturation strategies and the two notions: language learning strategies and agency (shown by arrow $\mathrm{C}$ ). This is to be done by narrating the process undergone by students who have used different acculturation strategies and this serves as the answer to fulfill the purpose of exploring how ISs experience English language learning in a hybrid environment.

\section{CONCLUSION}

The conceptual framework presented in this article is an initial but crucial part of a bigger research. This article has emphasised the tenets from four theories/model that underpin the study and discussed the major themes of language learning strategies (LLS) and international students (ISs) with their peripheral aspects of hybrid environment, acculturation and agency. The deliberation of both the theories and themes has highlighted the four notions (hybrid environment, agency, out-of-class language learning strategies and acculturation strategies) that become the pillars of the conceptual framework in exploring the English language learning experiences of international students in Malaysia.

\section{REFERENCE LIST}

Adel, A. R. (2011). Effects of $L 2$ proficiency and gender on choice of language learning strategies by university students majoring in English. Asian EFL Journal Quarterly, 13(1), 114-162.

Alavi, M., \& Mansor, S. M. S. (2011). Categories of Problems among International Students in Universiti Teknologi Malaysia. Procedia- Social and Behavioral Sciences, 30, 1581-1587. doi: 10.1016/j.sbspro.2011.10.307

Andrade, M. S. (2006). International students in English-speaking universities: Adjustment factors. Journal of Research in International Education, 5(2), 131-154.

Arkoudis, S., \& Love, K. (2008). Imagined communities in senior school mathematics: Beyond issues of English language ability. The Asia Pacific Communication: Special issue Chinese students: Perspectives on their social, cognitive, and linguistics investment in English medium interaction, 18 (1), 71-90.

Arkoudis, S., \& Tran, L.T. (2007). International students in Australia: Read ten thousand volumes of books and walk ten thousand miles. Asia Pacific Journal of Education, 27(2), 157-169.

Atkinson, D. (2011). A sociocognitive approach to second language acquisition: How mind, body, and world work together in learning additional languages. In: Atkinson, D. (ed.). Alternative approaches to second language acquisition. New York: Routledge, 143-166.

Ballard, B. \& Clanchy, J. (1997). Teaching international students : A brief guide for lecturers and supervisors, Deakin: IDP Education Australia.

Bandura, A. (2001). Social Cognitive Theory: An Agentic Perspective. Annual Review Psychology, 52, 1-26.

Bandura, A. (2005). The evolution of social cognitive theory. In K. G. Smith \& M. A. Hitt (Eds.), Great Minds in Management (pp. 9-35). Oxford: Oxford University Press.

Bandura, A. (2006). Toward a Psychology of Human Agency. Perspectives on Psychological Science, 1(2), 164-180.

Beard, C., \& Wilson, J. P. (2007). Experiential Learning: A Best Practice Handbook for Educators and Trainers (2nd ed.). New Delhi: Kogan Page.

Bell, M. (2008). Exploring fieldwork for study abroad sojourners. In M. Hellsten \& A. Reid (Eds.), Researching international pedagogies (pp. 129-150), Dordrecht : Springer. 
Bernat, E., Davies, M., \& Ritchie, C. (2009). Language learning strategies of international students: Five Australian universities investigated. A study funded by Australian Learning \& Teaching Council (A. L. T. Council, Trans.). Australia.

Berry, J.W. (2005). Acculturation: Living successfully in two cultures. International Journal of Intercultural Relations, 29, 697-712.

Berry, J.W., Kim, U., Minde, T., \& Mok, D. (1987). Comparative studies of acculturative stress. International Migration Review, 21(3), 491-511.

Bialystok, E. (1978). A theoretical model of second language learning. Language Learning 28: 69-83.

Birrel, B. (2006). Implications of low English standards among overseas students at Australian universities. People and Place, 14(4), 53-64.

Bradley, D., \& Bradley, M. (1984). Problems of Asian students in Australia: Language, culture and education. Canberra: Government Publishing Service.

Caroll, J. (2005). 'Lightening the load': Teaching in Enlgish, learning in English. In J. Caroll \& J. Ryan (Eds.), Teaching International Students: Improving Learning for all (pp. pp. 35-42). NY: Routledge.

Cuthbert, D., Smith, W., \& Boey, J. (2008). What do we really know about the outcomes of Australian international education? A critical review and prospectus for future research. Journal of Studies in International Education, 12, 255-275.

Davies, B. (1990). Agency as a form of discursive practice. A classroom scene observed. British Journal of Sociology of Education, 11(3), 341-361.

Dawson, J., \& Hacket, J. (2006). Developing service quality for international students. Paper presented at the Australian International Conference 2006. Retrieved February 15, 2010, from www.idp.com/aiec

Doherty, C., \& Singh, P. (2005). How the West is done: Simulating Western pedagogy in a curriculum for Asian international students. In P. Ninnes \& M. Hellsten (Eds.), Internationalizing higher education: Critical explorations of pedagogy and policy (pp. pp. 53-74). Hong Kong: Comparative Education Research Centre.

Ellis, R. (1994). The Study of Second Language Acquisition. Oxford: Oxford University Press.

El-Saleh, A. H. E.-O. (2002). Language Learning Strategies employed by Jordanian Secondary School Students Learning English as a Foreign Language. PhD, Universiti Kebangsaan Malaysia.

English Language History (n.d) Retrieved 18 August 2012, 2012, from http://www.englishlanguageguide.com/english/facts/history

Ferman, T. (2003). Ways forward in developing the writing skills of international students. In A. J. Liddicoat, S. Eisenchlas \& S. Trevaskes (Eds.), Australian perspectives on internationalising education (pp. pp. 3952). Melbourne: Language Australia.

Foo, B., \& Richards, C. (2004). English in Malaysia. RELC Journal, 35(2), 229-240.

Gao, X. (2006). Understanding changes in Chinese students' uses of learning strategies in China and Britain: A socio-cultural re-interpretation. System, 34(1), 55-67. doi: 10.1016/j.system.2005.04.003

Gao, X., Cheng, H. \& Kelly, P. (2008). Supplementing an uncertain investment? Mainland Chinese students practicing English together in Hong Kong. The Asia Pacific Communication: Special issue Chinese students: Perspectives on their social, cognitive, and linguistics investment in English medium interaction, 18 (1), 9-29.

Green, J. M., \& Oxford, R. (1995). A closer look at learning strategies, L2 proficiency, and gender. TESOL Quarterly, 29(2), 261-297.

Griffiths, C. (2003). Patterns of language learning strategy use. System, 31(3), 367-383. doi: 10.1016/s0346$251 \times(03) 00048-4$

Gu, M. (2008). Identity construction and investment transformation: College students from non-urban areas in China. The Asia Pacific Communication: Special issue Chinese students: Perspectives on their social, cognitive, and linguistics investment in English medium interaction, 18 (1), 49-70.

Gu, Y. (2002). Gender, Academic Major, and Vocabulary Learning Strategies of Chinese Efl Learners. RELC Journal, 33(1), 35-54. doi: 10.1177/003368820203300102 
Guilfoyle, A. M., \& Harryba, S. (2009). Understanding Seychelles internationa students' social and cultural experiences during transition to an Australian university. The International Journal of Learning, 16(11), $1-22$.

Gul, V., \& Kolb, S. (2009). Acculturation, bicultural identity and psychiatric morbidity in young Turkish patients in Germany. Turkish Journal of Psychiatry. 1-7.

Harman, G. (2005). Internationalization of Australian higher education: A critical review of literature and research. . In P. Ninnes \& M. Hellsten (Eds.), Internationalizing higher education: Critical explorations of pedagogy and policy (pp. pp. 119-140). Hong Kong: Comparative Education Research Centre.

Hellsten, M. (2008). Researching international pedagogy and the forming of new academic identities. In M. Hellsten \& M. Reid (Eds.), Researching international pedagogies (pp. pp. 83-98). Dordrecht: Springer.

Irgin, P. (2011). Listening strategies used by Turkish students learning English as a foreign language: The development of 'Listening Strategy Inventory'. Master, Mersin University, Turkey, Mersin.

Izawati@ @iti Zawiyah, I. (2008). English Language Strategies Used by Polytechnic Students. Master, Universiti Kebangsaan Malaysia.

Jiang, M., Green, R. J., Henley, T. B., \& Masten, W. G. (2009). Acculturation in relation to the acquisition of a second language. Journal of Multilingual and Multicultural Development, 30(6), 481-492.

Johari Afrizal. (2005). Language Learning Strategies of EFL University Students at an Indonesian Private University. Master, Universiti Kebangsaan Malaysia.

Kamarul Shukri, Mohamed Amin, Nik Mohd Rahimi, \& Zamri. (2009). Language learning strategies and motivation among religious secondary school students. The International Journal of Language Society and Culture(29), 71-79.

Kashefian-Naeeini, S., \& Nooreiny, M. (2010). A Study of the Use of Language Learning Strategies among Students in Iran. Malaysian Journal of ELT Research, 6, 195-233.

Kashefian-Naeeini, S., Nooreiny, M., \& Hadi, S. (2011). Malaysian ESL Learners' Use of Language Learning Strategies. Paper presented at the 2011 International Conference on Humanities, Society and Culture, Singapore.

Kerr, I. (2011). Championing the MY Education Brand. Paper presented at the The 15th Malaysia Education Summit 2011, Bandar Sunway, Malaysia.

Khairi, O. A.-Z., \& Rechards, C. (2010). Arab Postgraduate Students in Malaysia: Identifying and overcoming the cultural and language barriers. Arab World English Journal, 1(1), 107-129.

Kolb, A. Y., \& Kolb, D. A. (2005). Learning styles and learning spaces: Enhancing experiential learning in higher education. Academy of Management Learning and Education, 4(2), 193-212.

Kolb, D. A. (1984). Experiential learning: experience as the source of learning and development: Prentice-Hall.

Kolb, D. A., Boyatzis, R. E., \& Mainemelis, C. (2000). Experiential Learning Theory: Previous research and new directions. In R. J. Sternberg \& L. F. Zhang (Eds.), Perspectives on Cognitive, Learning, and Thinking Styles. New Jersey: Lawrence Erlbaum.

Lantolf, J. P. (2000). Introducing Sociocultural Theory Sociocultural Theory and Second Language Learning (pp. 1-26). Oxford: Oxford University Press.

Lee, K. O. (2003). The relationship of school year, sex and proficiency on the use of learning strategies in learning English of Korean junior high school students. ASIAN EFL Journal, 1-36.

Lee, S. K., Lee, K. S., Wong, F. F., \& Azizah, Y. A. (2010). The English language and its impact on identities of multilingual Malaysian undergraduates. GEMA Online ${ }^{\mathrm{TM}}$ Journal of Language Studies, 10(1), 87-102.

Macaro, E. (2006). Strategies for Language Learning and for Language Use: Revising the Theoretical Framework. The Modern Language Journal, 90(3), 320-337.

Mamour, C. T. (2008). The relevance and implications of Vygotsky's sociocultural theory in the second language classroom. ARECLS, 5, 244-262.

Manjula, J., \& Slethaug, G. (2011). The Business of Education : Improving International Student Learning Experiences in Malaysia. Paper presented at the 14th International Business Research Conference, Dubai UAE. 
Manprit Kaur, \& Mohamed Amin Embi. (2011). The relationship between language learning strategies and gender among primary school students. Theory and Practice in Language Studies, 1(10), 1432-1436. doi: $10.4304 /$ tpls.1.10.1432-1436

Model for success? Malaysia's recent initiatives to enhance the international competitiveness of its higher education system. (2008) The Observatory on borderless higher education (pp. 1-3). London.

Mohamed Amin Embi. (2000). Language learning strategies: A Malaysian context. Bangi: Fakulti Pendidikan.

Mohamed Amin, E. (1996). Language learning strategies employed by secondary school students learning English as a foreign language in Malaysia. PhD, University of Leeds.

Mohd Taib, H. D., Nik Rahila, D. W. I., Sharimllah, D. R., Anisah, K., \& Mohd Shamsuri, M. S. (2009). A study on factors that influence choice of Malaysian institution of higher learning for international graduate students. Journal of Human Capital Development, 2(1), 105-115.

MoHE (Ministry of Higher Education). (2010). Data Makro Pengajian Tinggi. Retrieved from www.mohe.gov.my/web_statistik/.

Morshidi, S. (2008). The impact of September 11 on international student flow into Malaysia: Lessons learned. IJAPS, 4(1), 79-95.

Mousavi, H. S., \& Kashefian-Naeeini, S. (2011). Academic Writing Problems of Iranian Post-Graduate Students at National University of Malaysia (UKM). European Journal of Social Sciences, 23(4), 593603.

Murugesan, V. (2003). Malaysia promotes excellence in English. ESL Magazine, 26-28.

Myles, C., \& Cheng, L. (2003). The social and cultural life of non-native English speaking international graduate students at a Canadian university. Journal of English for Academic Purposes, 2, 247-263.

Nada, M. S. (2006). The Role of Motivation, Gender, and Language Learning Strategies in EFL Proficiency. Master, American University of Beirut, Beirut.

Noor Saazai, M.S., Melor M.Y, \& Mohamed Amin, E. (2012). Research on international students in traditional host countries and Malaysia: Some potential areas in Malaysia. Paper presented at the $6^{\text {th }}$ International Conference on University Teaching and Learning (InCULT) 2012, Concorde Hotel, Shah Alam, 20- 21 November 2012.

Novera, I. A. (2004). Indonesian postgraduate students studying in Australia: An examination of their academic, social and cultural experiences. International Education Journal, 5(4), 475-487.

O'Malley, J.M. \& Chamot, A.U. (1990). Learning Strategies in second language acquisition. Cambridge: Cambridge University Press.

Oxford, R. L. (2011a). Teaching and researching language learning strategies. Great Britain: Pearson Educational Limited.

Oxford, R. L. (2011b). Strategies for learning a second or foreign language. Language Teaching 44(02): 167180.

Oxford, R. L. (1996). Preface: Why is culture important for language learning strategies? In R. L. Oxford (Ed.), Language Learning Strategies Around the World: Cross-Cultural Perspectives (pp. ix-xv). Honolulu: University of Hawaii.

Oxford, R.L. (1990). Language Learning Strategies: What Every Teacher Should Know. Rowley: Newsbury House.

Pavlenko, A. \& Blackledge, A. (2004). Negotiation of Identities in Multilingual Contexts. Clevedon: Multilingual Matters Ltd.

Pawapatcharaudom, R. (2007). An investigation of Thai students' English language problems and their learning strategies in the international program at Mahidol University. Master, King Mongkut's Institute of Technology North Bangkok, Bangkok.

Pierce, B.N. (1995). Social identity, investment, and language learning. TESOL Quarterly, 29(1), 9-31.

Rohaizat, B., Zubaidah, A., \& Siti Falinda, P. (2011). International students choice criteria for selection of higher learning in Malaysian private universities. African Journal of Business Management, 5(12), 4704-4714. 
Rohana, J., Yong Zulina, Z., Huam, H. T., \& Abdul Hafaz, N. (2010). International Students' Views of Malaysian Higher Education. Paper presented at the Internationalisation and Marketing of Higher Education Malaysia Seminar : Bringing the World to Malaysia and Malaysia to the World, Putrajaya.

Sakurai, T., McCall-Wolf, F., \& Kashima, E. S. (2009). Building intercultural links: The impact of a multicultural intervention programme on social ties of international students in Australia. International Journal of Intercultural Relations, 1-10.

Sawir, E. (2005). Language difficulties of international students in Australia: The effects of prior learning experience. International Education Journal, 6(5), 567-580.

Sayers, J., \& Franklin, T. (2008). Culture shock! Cultural issues in a tertiary course using reflective techniques. Reflective Practice, 9(1), 79-88.

Schmidt, G. \& Jansen, L. M. (2003). Enhancing overseas study. In A.J. Liddicoat, S. Eisenchlas \& S.Trevaskes (Eds.), Australian perspectives on internationalising education (pp. 129-140), Melbourne: Language Australia.

Shmais, W. A. (2003). Language learning strategy use in Palestine. TESL-EJ, 7(2).

Su, M. M. (2005). A study of EFL technological and vocational college students' language learning strategies and their self-perceived English proficiency.Electronic Journal of Foreign Language Teaching, 2(1), 4456. Retrieved from http://e-flt.nus.edu.sg/

Tanahashi, S. (2009). Language learning strategies and the Japanese student. Journal of Bunkyo Gakuin University, 9, 123-131.

Thirusanku, J., \& Yunus, M. M. (2012). The Many Faces of Malaysian English. ISRN Education, 2012, 1-14. doi: $10.5402 / 2012 / 138928$

Thompson, F. (2009), May 23. Campus crimes. Newcastle Herald, p.4.

Tragant, E., \& Victori, M. (2012). Language learning strategies, course grades, and age in EFL secondary school learners. Language Awareness, 1-16. doi: 10.1080/09658416.2011.609622

Trent, J. (2008). Promoting investment by Chinese learners in classroom discourse: Integrating content and language in the undergraduate classroom. The Asia Pacific Communication: Special issue Chinese students: Perspectives on their social, cognitive, and linguistics investment in English medium interaction, 18(1), 30-48.

Trevaskes, S., Eisenchlas, S. \& Liddicoat, A. J. (2003). Language, culture and literacy in the internationalization process of higher education. In A.J. Liddicoat, S. Eisenchlas \& S. Trevaskes (Eds.), Australian perspectives on internationalising education (pp. 1-12), Melbourne: Language Australia.

Vann, R. J., \& Abraham, R. G. (1990). Strategies of unsuccessful language learners. TESOL Quarterly, 24(2), 177-198.

Verbik, L., \& Lasanowski, V. (2007). International Students Mobility: Patterns and Trends The Observatory on borderless higher education. London.

Vygotsky, L. (1978). Interaction Between Learning and Development Mind and Society (pp. 79-91). Cambridge: Harvard University Press.

Wu, I.-J. (2011). Learning strategies use by International Students from Taiwan in a university context: A case study. Master, California State University, Chico.

Yusliza Mohd. Yusoff, \& Chelliah, S. (2010). Adjustment in international students in Malaysian public university. International Journal of Innovation, Management and Technology, 1(3), 275-278.

Zainurin, D., \& Muhamad Abduh. (2011). Factors influencing international students' choice towards universities in Malaysia. African Journal of Business Management, 5(26), 10615-10620.

Zamri Mahamod. (2004). Strategi pembelajaran bahasa Melayu di kalangan pelajar sekolah menengah. Doctoral Thesis, Universiti Kebangsaan Malaysia.

Zuria, M., Salleh, A., Saemah, R., \& Noriah, M. I. (2010). Challenges for International Students in Malaysia: Culture, Climate and Care. Procedia - Social and Behavioral Sciences, 7, 289-293. doi: 10.1016/j.sbspro.2010.10.040 